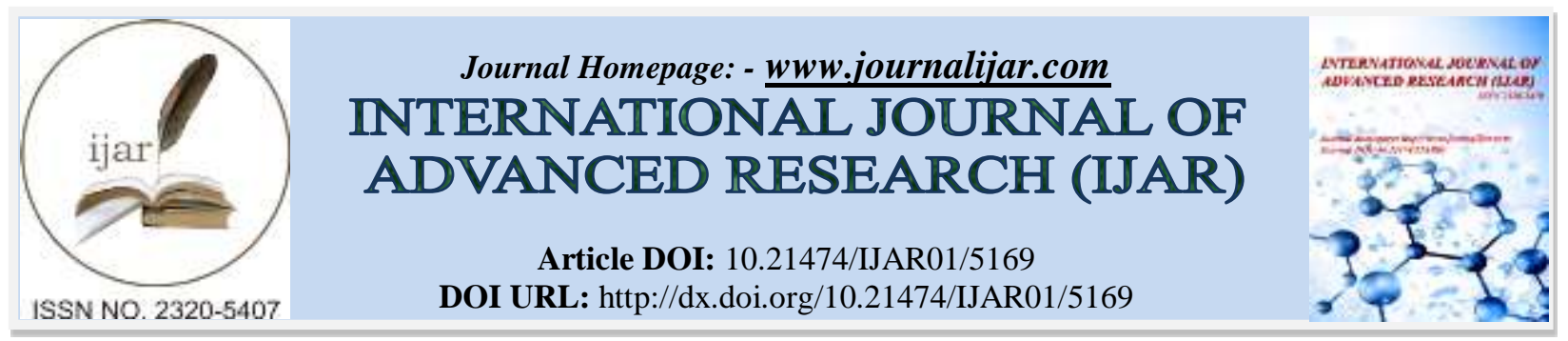

RESEARCH ARTICLE

\title{
ASSESSMENT OF BABESIA PREVALENCE IN SHEEP FROM PORO AREA (CÔTE D'IVOIRE).
}

\section{Nawolo Yéo ${ }^{1}$, "Yahaya Karamoko ${ }^{1}$, Zahouli Faustin Zouh Bi ${ }^{1}$, Abou Joel Landry Okon ${ }^{1}$ and Seïdinan Ibrahima Traorée .}

1. Laboratoire de Biologie et Cytologie Animales, UFR Sciences de la Nature, Université Nangui Abrogoua, 02 BP 801 Abidjan 02, Côte d'Ivoire.

2. LANADA Laboratoire Regional de Korhogo (LRK), BP 32 Korhogo, Côte d'Ivoire.

Manuscript Info
Manuscript History
Received: 14 June 2017
Final Accepted: 16 July 2017
Published: August 2017
Key words:-
Babesia, sheep, prevalence, Poro area,
Côte d'Ivoire.

Babesia, sheep, prevalence, Poro area

\begin{abstract}
A total of 120 blood samples collected from Sheep in Poro area, were examined for haemoparasites using the blood smear method from December 2015 to April 2016 to determine the prevalence of Babesia species. Microscopic technique has been used to determine prevalence of Babesia (16.67\%) from the smears of sheep. Babesia bigemina and Babesia bovis were the two Babesia species recorded with a high prevalence for Babesia bigemina (11.67\%). In addition, Babesia bigemina and Babesia bovis were more met respectly in the departments of Sinematiali (30\%) and Dikodougou (13.33\%). The adults sheep ( 9 months of age) and the female sheep were most infected by Babesia. The prevalences were respectly $17.86 \%$ and $19.30 \%$. Mixed infections with these parasites were common at the prevalence of $1.67 \%$. We concluded that this study made it possible to show the presence of Babesia in the sheep of Poro area. These results provide information to the veterinary technicians.
\end{abstract}

Copy Right, IJAR, 2017,. All rights reserved.

\section{Introduction:-}

Haemoparasites have generally been shown to cause destruction of red blood cells resulting in anaemia, anorexia, high morbidity and mortality, infertility, jaundice and weight loss (Ademola and Onyiche 2014; Sharifi et al., 2016 ; Opara et al., 2016). Haemoparasitism in small ruminants caused by the various haemoparasites is widespread throughout the world, and they occur in temperate, tropical and subtropical regions (Ukwueze and Ekenma 2015; Opara et al., 2016). Babesiosis is a tick-borne haemoparasitic disease affecting a wide range of domestic and wild animals and is caused by the genus Babesia. It comprises many species of parasites that infect a large range of erythrocytes and various vertebrate hosts (Vannier and Krause, 2009; Qingli et al., 2016). Babesia bigemina and Babesia bovis are blood parasites responsible of babesiosis for domestic ruminants. This disease used to affect the exchanges of the livestock products (Mohammad et al., 2013). It's constitutes an economic constraint for breeding (Simuunza et al., 2016) and a major problem for the sheep breeding (Shahbazi et al., 2013). It's characterized by anaemia, fever and blood urine (Martins et al., 2008). The genus tick Rhipicephalus (Boophilus) is the principal vector of these pathogenic. This tick is present in tropical and subtropical countries and in particular in the South (Madder et al., 2011) and the North (knopf et al., 2002) of Côte d'Ivoire This area, within the most important manpower of the bovine national livestock (Tangui, 2008), is favorable to the development of the domestic ruminants breeding. 


\section{Material and methods:-}

\section{Area}

The study area is located in the north of Côte d'Ivoire. Four departments were retained for this study: Sinematiali, Korhogo, Dikodougou and M'Bengue (Figure 1). This border area of Mali and Burkina Faso are mainly characterized by a Sudanese climate. Two seasons are observed in Poro area: rainy season from April to October and a dry season from November to March and under the influence of a dry and hot wind from the Sahara.

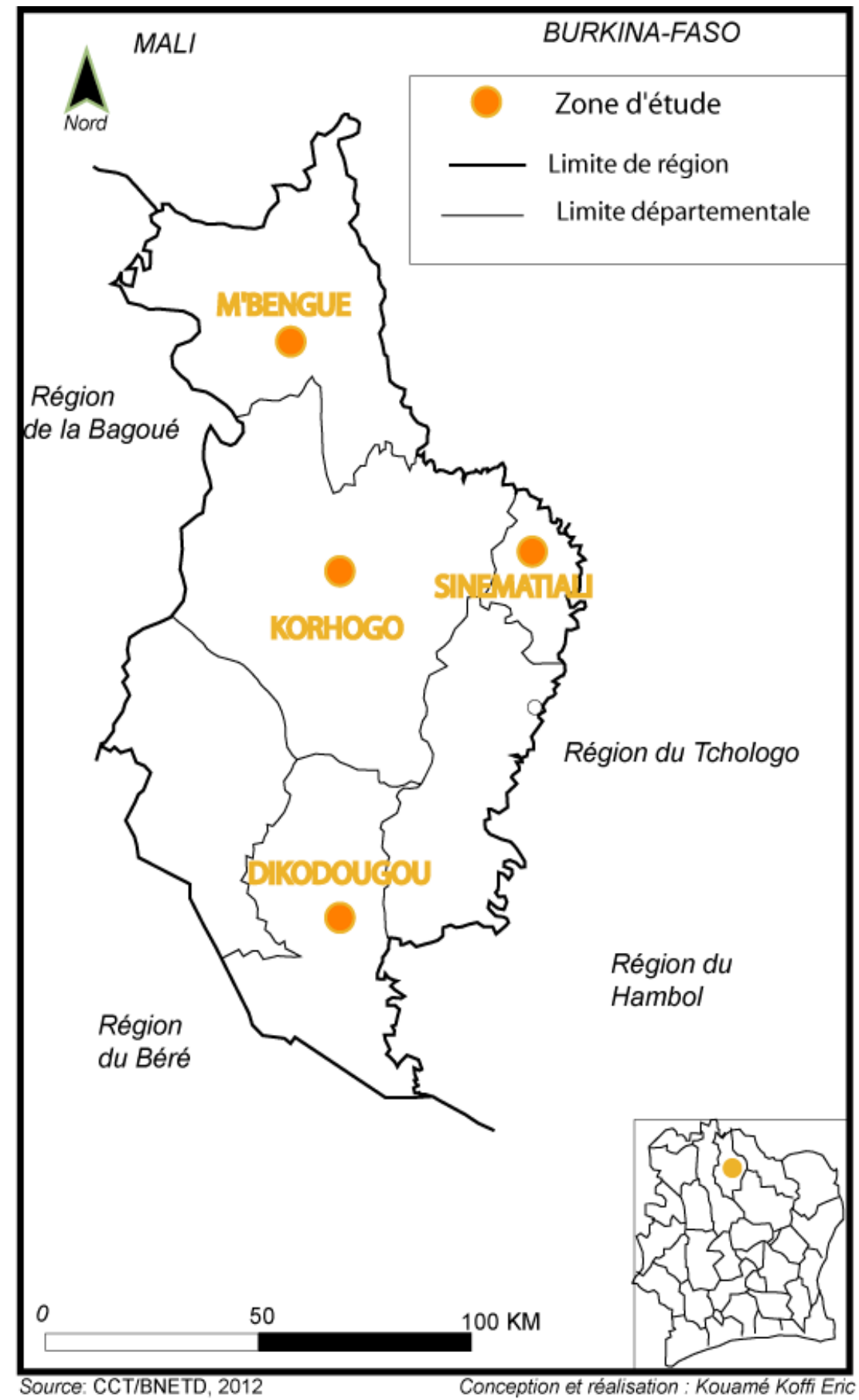

Figure 1:- Area of Poro within the study departments. 


\section{Sample collection:-}

A total of 120 blood sample were collected randomly from Poro area Sheep (Djallonke breed) between the months of December 2015 and April 2016. The blood was collected from ear-vein. The breeds of sheep sampled were the departments of Sinematiali, Korhogo, Dikodougou and M'Bengue localited in the Poro area of Côte d'Ivoire. Their distribution, according to age, sex and the department is shown in Table 1.

Table1:- Number of samples according to sheep age and sex in the departments

\begin{tabular}{|c|c|c|c|c|c|}
\hline \multirow[t]{2}{*}{ AGE } & \multicolumn{4}{|c|}{ Departments } & \multirow[t]{2}{*}{ Total } \\
\hline & Sinematiali & Korhogo & Dikodougou & M'Bengue & \\
\hline young ( $\leq 3$ months) & 0 & 0 & 0 & 0 & 0 \\
\hline Adult (3-9 months) & 5 & 0 & 2 & 1 & 8 \\
\hline Old (> 9 months) & 25 & 30 & 28 & 29 & 112 \\
\hline SEX & 27 & 30 & 27 & 30 & 114 \\
\hline 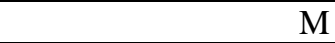 & 3 & 0 & 3 & 0 & 6 \\
\hline
\end{tabular}

Parasitological examination:-

Blood samples collected directly from an ear-vein in a heparinized micro hematocrit capillary tube, thin blood smears were drawn, air dried. At laboratory regional of Korhogo (LRK), the smears were fixed (methanol 3 to 5 min) and stained by immersing in jar containing diluted 10\% Giemsa solution for 20 to 30 min (Sitotaw et al., 2014), and after, smears were air dried and then examined under oil immersion $\times 100$ magnification to identify the morphology and type of Babesia.

\section{Statistical analyzes:-}

The prevalences were calculated as follows:

Prevalence $(\%)=\frac{\text { Number of positive blood smears }}{\text { Total number of smears examined }} \times 100$

The proportions of the various studied parameters were subjected to a Chi2 test to evaluate their significant level. The prevalences were significant at $5 \%$.

\section{Results:-}

Prevalence of Babesia according to the localities:-

For sheep, 20 cases of infection were detected out of the 120 sheep sampled, which is equivalent to a prevalence of $16.67 \%$. In addition, sheep of all the departments sampling were infected by Babesia. The higher prevalence (30\%) of Babesia was met in the department of Sinematiali. On the other hand, the department of M'Bengue was less infected (3.33\%). The prevalences of Babesia infection were significantly $(p<0.05)$ (Table 2).

\section{Prevalence of Babesia species according to the localities:-}

Two Babesia species were identified from the sheep during the microscopic observations of blood smears: Babesia bovis and Babesia bigemina in mono-infection with respective in total prevalences of $6.67 \%(n=8)$ and $11.67 \%(n=$ 14). Mixed infections of Babesia bovis and Babesia bigemina were also noted from sheep of Sinematiali with a prevalence of $1.67 \%$ with $\mathrm{n}=2$. In addition, the department of Sinematiali was higher infected by Babesia bigemina with a prevalence of 30\%. On the other hand, Babesia bovis was absent in the department of M'Bengue. The higher prevalence of Babesia bovis was $13.33 \%$ in the department of Dikodougou. The prevalences were significantly ( $<<$ 0.05) for Babesia bigemina between the different departments sampled (Figure 2).

\section{Prevalence variations of Babesia and species according to age and sex:-}

Babesia was met only in the old sheep of more than 9 months. In total prevalence in the Poro area was $17.86 \%$. The higher prevalence was $8.04 \%$ in the department of Sinematiali. The prevalences were significantly $(p<0.05)$ for the old sheep of more than 9 months in the different departments. Babesia bovis and Babesia bigemina were observed from the old sheep of more than 9 months. Babesia bigemina was more observed in this category sheep with a prevalence of $12.5 \%$ in the area sampled. In addition, mixed infections were met from females and the old sheep of more than 9 months with the prevalences respective of $1.75 \%$ and $1.79 \%$. The prevalences were significantly at $\mathrm{p}<$ 0.05 for the females and the old sheep of more than 9 months (Table 3).

Concerning sex, Babesia was met from the male and the female sheep. In total, the highest prevalence was met from the females with a prevalence of $19.30 \%$ and $16.67 \%$ for the males. In addition, the highest prevalence of Babesia 
was observed from the female sheep of the department of Sinematiali with a prevalence of $7.02 \%$. The prevalence of Babesia was significantly $(\mathrm{p}<0.05)$ in the female sheep of the sampled departments (Table 4).

Table 2:- Prevalence of Babesia according to departments

\begin{tabular}{|l|c|c|c|}
\hline Departments & $\begin{array}{c}\text { Number of } \\
\text { samples }\end{array}$ & $\begin{array}{c}\text { Number } \\
\text { of cases }\end{array}$ & $\begin{array}{c}\text { Prevalence } \\
(\%)\end{array}$ \\
\hline Sinematiali & 30 & 9 & $30^{\mathrm{a}}$ \\
\hline Korhogo & 30 & 3 & $10^{\mathrm{b}}$ \\
\hline Dikodougou & 30 & 7 & $23.33^{\mathrm{a}}$ \\
\hline M'Bengue & 30 & 1 & $3.33^{\mathrm{b}}$ \\
\hline Total & 120 & 20 & 16.67 \\
\hline
\end{tabular}

Prevalences in the same column, which bear the same letter, are not statistically different from the $5 \%$ threshold.

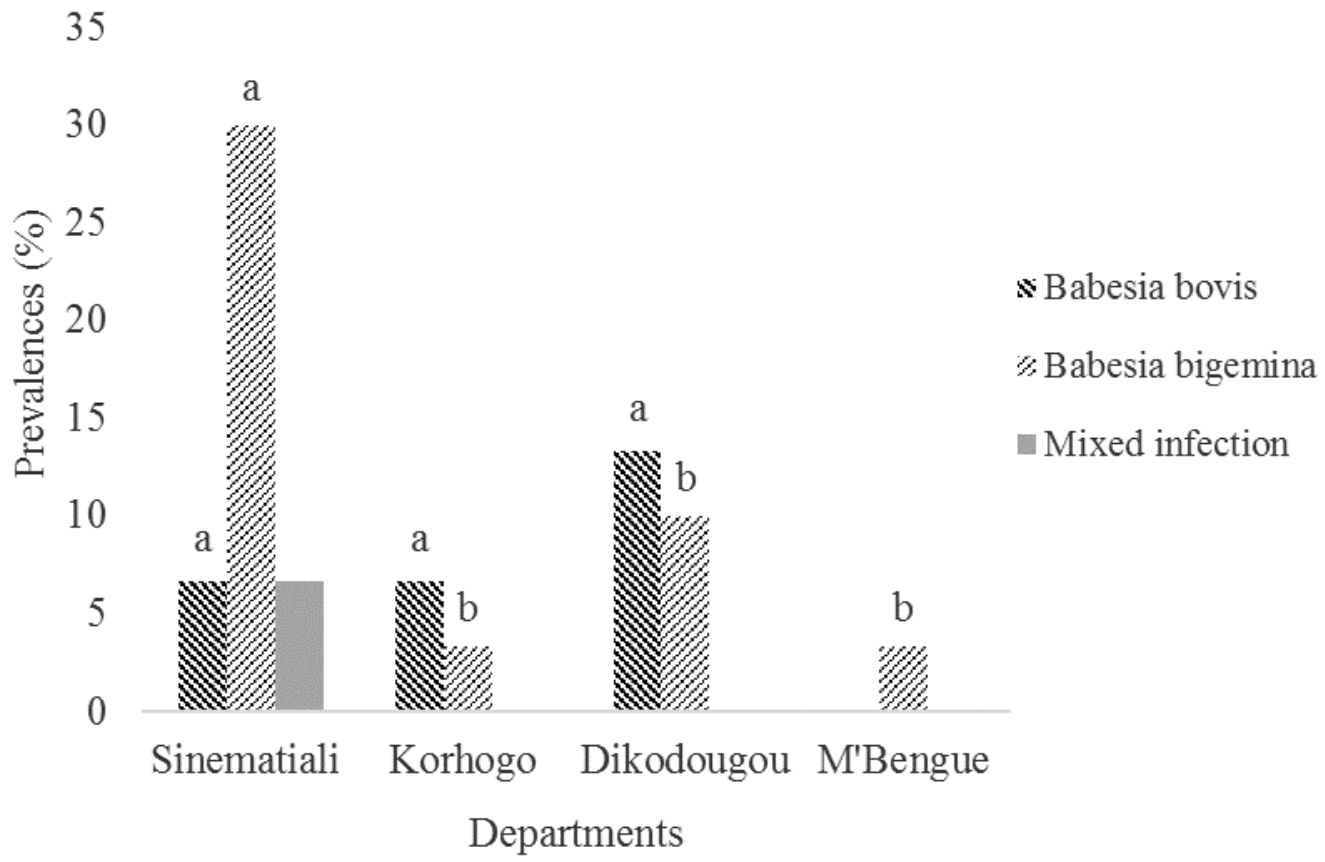

Figure 2:- Prevalence of Babesia species according to the localities

Table 3: Prevalence of Babesia in the departments according to sheep age and sex

\begin{tabular}{|c|c|c|c|c|c|}
\hline \multirow[t]{2}{*}{ Parameters } & \multicolumn{4}{|c|}{ Departments } & \multirow[t]{2}{*}{ Total } \\
\hline & Sinematiali & Korhogo & Dikodougou & M'Bengue & \\
\hline $\begin{array}{c}\text { AGE } \\
\text { Young ( } \leq 3 \text { months }) \\
\end{array}$ & 0 & 0 & 0 & 0 & 0 \\
\hline Adult (3-9months) & 0 & 0 & 0 & 0 & 0 \\
\hline Old (> 9 months) & $\begin{array}{l}8.04^{\mathrm{a}} \\
(9 / 112)\end{array}$ & $\begin{array}{c}2.68^{\mathrm{a}} \\
(3 / 112)\end{array}$ & $\begin{array}{l}6.25^{\mathrm{a}} \\
(7 / 112)\end{array}$ & $\begin{array}{c}0.89^{b} \\
(1 / 112)\end{array}$ & $\begin{array}{c}17.86 \\
(20 / 112)\end{array}$ \\
\hline SEX & $\begin{array}{l}7.02^{\mathrm{a}} \\
(8 / 114)\end{array}$ & $\begin{array}{c}2.63^{\mathrm{a}} \\
(3 / 114)\end{array}$ & $\begin{array}{c}8.77^{\mathrm{a}} \\
(10 / 114)\end{array}$ & $0.88^{b}$ & $\begin{array}{c}19.30 \\
(22 / 114)\end{array}$ \\
\hline $\mathrm{M}$ & $\begin{array}{r}16.67 \\
(1 / 6) \\
\end{array}$ & 0 & 0 & 0 & $\begin{array}{r}16.67 \\
(1 / 6) \\
\end{array}$ \\
\hline
\end{tabular}

Prevalences in the same line, which bear the same letter, are not statistically different from the 5\% threshold.

Table 4:- Prevalence of species Babesia according to the sheep age and sex

\begin{tabular}{|l|c|c|c|}
\hline Parameters & Babesia bovis & Babesia bigemina & $\begin{array}{c}\text { Babesia bovis }+ \text { Babesia } \\
\text { bigemina }\end{array}$ \\
\hline AGE & 0 & 0 & 0 \\
\hline
\end{tabular}




\begin{tabular}{|c|c|c|c|}
\hline \multicolumn{4}{|l|}{ Young ( $\leq 3$ months $)$} \\
\hline Adult (3-9months) & 0 & 0 & 0 \\
\hline Old (> 9months) & $7.14^{\mathrm{a}}(8 / 112)$ & $12.5^{\mathrm{ab}}(14 / 112)$ & $1.79^{\mathrm{ab}}(2 / 112)$ \\
\hline SEX & $7.02^{\mathrm{a}}(8 / 114)$ & $11.40^{\mathrm{ab}}(13 / 114)$ & $1.75^{\mathrm{ab}}(2 / 114)$ \\
\hline M & 0 & $16.67(1 / 6)$ & 0 \\
\hline
\end{tabular}

Prevalences in the same line, which bear the same letter, are not statistically different from the $5 \%$ threshold.

\section{Discussion:-}

The study has revealed the presence of Babesia in sheep breeding in the Poro area of Côte d'Ivoire with a total prevalence of $16.67 \%$. Similary prevalence was obtained by Opara et al., (2016) from sheep in the Guinea Savannah Zone of Nigeria. In this area, $20.2 \%$ of the small ruminants were infected with haemoparasites. The prevalence of Babesia was $4.8 \%$. This value was lower than the prevalence obtained in the present study (16.67\%). However, this was not in agreement with previous study undertaken by Bell-Sakyi et al., (2004) and Sitotaw et al., (2014). They had obtained no existence of Babesia in the sheep while present within the bovines. The present result could be explained by the mixed control of cattle and sheep in the breed sampled. Indeed, cattle and sheep used the same pasture and also, ticks was not fought within sheep because its constituted an ancillary activity. According to Adamu and Balarabe (2012), heamoparasitic infections were found within Slaughtered sheep and Goats in Bauchi Abattoir of Nigeria, when they have been reared in the same area. The presence of Babesia could be attributed equally to the favorable environmental conditions for the survival and proliferation of the arthropod vectors responsible for their transmission. Moreover, the tick of genus Rhipicephalus which inoculated Babesia to ruminants was successively identified in the north of Côte d'Ivoire by Knopf et al., (2002) and Achi et al., (2012).

The higher prevalence $(30 \%)$ of Babesia was met in the department of Sinematiali. With the statements of the stock breeders, this department would constitute a corridor of transhumance of the bovines from Mali and Burkina Faso and, most-favoured infestation of local livestock. The frequentation of Mali and Burkina Faso cattle could be at the origin of the local sheep infection.

Mixed infections were observed in the area sampled with a prevalence of $1.67 \%$. The presence at the same time of these two species of Babesia could be explained by a probable infestation of the sheep by the ticks Rhipicephalus (Boophilus) microplus and Boophilus annulatus first infected by the two species of Babesia in the study site. In addition, on the 2515 smears collected in the north of Côte d'Ivoire, Babesia bovis (0.12\%) and Babesia bigemina $(0.04 \%)$ were observed from the crossbreed (Montbeliard and Holstein) (Achi et al., 2012). Then, Babesia bovis was met from the bovine by Djakaridja et al., (2014) in the North of Côte d'Ivoire with a prevalence of 45.28\%.

Babesia bigemina was more observed in the sheep with a prevalence of $11.67 \%$ in the area sampled. Its prevalence was almost the double of that observed for Babesia bovis (6.67\%). Similary result was obtained by Opara et al., (2016). Babesia was observed in the adult sheep with a higher prevalence (18.2\%). The younger sheep was not infected by this parasite. However, this result is not in agreement with previous study by Christophe (2009). Indeed, according to this author, Babesia bigemina and Babesia divergens are more present in the blood of the jugular vein. Whereas in the case of our study, the peripheral blood was collected from the ear-vein. In addition, the modification of the climate observed in these last years in the North of Côte d'Ivoire could be at the origin of this difference in results. Babesia was met only in the old sheep of more than 9 months with a total prevalence of $17.86 \%$. Indeed, the sheep sampled were old than 9 months.

Babesia was met from the male and the female sheep. This result is in agreement with previous study by Opara et al., (2016) where $5.6 \%$ of Males and $21.4 \%$ of Females were infected.

\section{Conclusion:-}

This study has confirmed the presence of Babesia infection on sheep breeding in Poro area, in the north of Côte d'Ivoire. Babesia bigemina was more observed than Babesia bovis. The mixed control of cattle and sheep could spred out Babesia infection in the north of Côte d'Ivoire. This situation represents a constraint for the introduction of foreign breeds in the north of Côte d'Ivoire. It is therefore important, for successful farming, to stop mixed control breedings of bovines and all other animal species in particular the sheep. 


\section{Acknowledgements:-}

The authors gratefully acknowledge the technical staff of Regional Laboratory of Korhogo (LRK) and the farmers who accepted to participate at this study.

\section{References:-}

1. Achi, Y.L., Koné, P., Stachurski, F., Zinsstag, J. and Betschart, B. (2012). Impact des tiques sur des bovins métissés dans le Nord de la Côte d'Ivoire. Bull Anim Health Prod Afr., 60(2): 109-118.

2. Adamu, B.S. and Balarabe, L.M. (2012). Prevalence of Haemoparasites of Sheep and Goats Slaughtered in Bauchi Abattoir. Int J Appl Biol Res., 4(1\&2): 128-133

3. Ademola, I.O. and Onyiche, T.E. (2014). Haemoparasites and haematological parameters of slaughtered Ruminants and pigs at Bodija Abattoir, Ibadan, Nigeria. Afr. J. Biomed. Res., 16(2): 101-105.

4. Bell-Sakyi, L., Koney, E.B.M., Dogbey, O. and Walker, A.R. (2004). Incidence and prevalence of tick-borne haemoparasites in domestic ruminants in Ghana. Vet. Parasitol., 124: 25-42.

5. Christophe, J. (2009). L'anaplasmose bovine à Anaplasma marginale et les babésioses bovines, situation en France métropolitaire et sur l'Ile de la réunion. Clinique vétérinaire des Hauts, 259 rue Jules Bertaut, 97430 Le Tampon, Ile de la Réunion. Bull. Soc. Vét. Prat. de France, avril/mai/juin, 93(2) : 34-41.

6. Djakaridja, B., Yao, K.P., Gragnon, B.G., Acapovi-Yao, G. and Mavoungou, J.L. (2014). Situation épidémiologique des hémoparasittes des bovins dans deux zones d'élevage de la Côte d'Ivoire: cas des anciennes régions des savanes et de la vallée Bandama. Rev Méd Vét., 165 : 297-303.

7. Knopf, L., Komoin-Oka, C., Betschart, B., Jongejan, F., Gottstein, B. and Zinsstag J. (2002). Seasonal epidemiology of ticks and aspects of cowdriosis in N'Dama village cattle in the Central Guinea savannah of Côte d'Ivoire. Prev Vet Med., 53(1-2): 21-30

8. Madder, M., Thys, E., Achi, L., Toure, A. and de Deken, R, (2011). Rhipicephalus (Boophilus) microplus: a most successful invasive tick species in West-Africa. Exp Appl Acarol., 53: 139-145.

9. Mohammad, H.T., Sedigheh, N., Mahdi, K., Homan, R. and Abbas, G.S. (2013). Study on prevalence of blood parasites of sheep and detection of their vectors using methyl green pyronin in Varamin, Iran. Pelagia Research Library. Euro. J. Exp. Bio., 3(5): 11-15.

10. Opara, M.N., Santali, A., Mohammed, B.R. and Jegede, O.C. (2016). Prevalence of Haemoparasites of Small Ruminants in Lafia Nassarawa State: A Guinea Savannah Zone of Nigeria. J. Vet. Adv., 6(6): 1251-1257.

11. Qingli, N., Zhijie, L., Jifei, Y., Peifa, Y., Yuping, P., Bintao, Z., Jianxun, L., Guiquan, G. and Hong, Y. (2016). Expression of sheep pathogen Babesia sp. Xinjiang rhoptryassociated protein 1 and evaluation of its diagnostic potential by enzyme-linked immunosorbent assay, Parasitol Res. : 1-10.

12. Simuunza, M., Weir, W., Courcier, E., Tait, A. and Shiels, B. (2016). Epidemiological analysis of tick-borne diseases in Zambia. Vet Parasitol., 175(3-4): 331-342.

13. Sitotaw, T., Regassa, F., Zeru, F. and Kahsay, A.G. (2014). Epidemiological significance of major hemoparasites of ruminants in and around Debre-Zeit, Central Ethiopia. J. Parasitol. Vector Biol., 6(2) : 16-22.

14. Shahbazi, A., Fallah, E., Mamagani, A.J., Khanmohammadi, M., Nematollahi, A. and Bazmani, A. (2013). Identification of Babesia Species in Sheep Isolated from Villages of East Azerbaijan by Semi-nested PCR. J Pure Appl Microbiol., 7(1) : 201-205.

15. Sharifi, N., Ganjali, M., Nabavi, R. and Saadati, D. (2016). A study on prevalence and identification of Ovine Theileria and Babesia infection in Zabol using PCR method. J Parasit Dis. : 1-5.

16. Tanguy, Le G. (2008). Le développement agricole et pastoral du nord de la Côte d'Ivoire : Problème de coexistence, les cahiers d'outre-mer., pp : 226-227.

17. Ukwueze, C.S. and Ekenma, K. (2015). Prevalence of haemoparasites in red sokoto goats slaughtered at Ahiaeke Market, Umuahia, Abia State, Nigeria. J Vet Adv., 5(2): 826-830.

18. Vannier, E. and Krause, P.J. (2009). Update on babesiosis. Interdiscip Perspect Infect Dis., 98 : 45-68. 